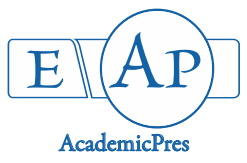

\author{
Aderiye KOS et al. (2021) \\ Notulae Scientia Biologicae 13(1):10833 \\ DOI: $10.15835 / \mathrm{nsb} 13110833$ \\ Research Article
}

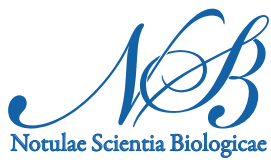

\title{
Response of groundnut (Arachis hypogaea L.) genotypes to accelerated ageing treatment
}

\section{Kehinde O.S. ADERIYE ${ }^{1}$, Tolulope O. KEHINDE², Johnson A. ADETUMBI $^{1 *}$, Dotun J. OGUNNIYAN ${ }^{1}$, Moruf A. ADEBISI ${ }^{2}$}

\author{
${ }^{1}$ Institute of Agricultural Research and Training, P.M.B. 5029, Moor Plantation, Ibadan, \\ Nigeria;solaaderiye@yahoo.com; dotunogunniyan@yahoo.com; \\ ${ }^{2}$ Federal University of Agriculture, P.M. B. 2240, Abeokuta, Nigeria; kehindeto@funaab.edu.ng; \\ jaadetumbi@yahoo.com (*correspondingauthor)
}

\begin{abstract}
Reduction in germination of crop seeds due to depletion of food reserves and decline in synthetic activity due to ageing has become a serious concern to groundnut growers who need adequate, high quality seeds to sustain groundnut production. Therefore, to stimulate farmers' interest in groundnut production, an experiment was conducted to evaluate some groundnut varieties for their tolerance to seed ageing stress, with a view to recommending varieties that can be considered for production in tropical countries. Seeds of nine elite groundnut genotypes, sourced from The International Crops Research Institute of Semi-Arid Tropics (ICRISAT), Kano and three other genotypes sourced from local seed dealer in Ibadan, Nigeria were subjected to seed quality assessments in the seed testing laboratory of Institute of Agricultural Research and Training, Ibadan. The seed lots were subjected to accelerated ageing procedures of $42{ }^{\circ} \mathrm{C}$ temperature and $100 \%$ relative humidity for 24 hours. Twenty-five seeds of each genotype were drawn from each genotype in three replicates at 3, 6, 12 and 24 hours of ageing. The drawn samples were reassessed to determine their tolerance ability to ageing stress. Percentage germination was transformed using arc-sine before the data on preliminary seed germination and seedling vigour data and seed ageing data were subjected to analysis of variance (ANOVA) using SAS ${ }^{\text {mit }}$ Means were separated using Duncan Multiple Range Test (DMRT) at 5\% level of significance while k-means non-hierarchical clustering analysis was used to group the genotypes based on their response to the ageing. Result showed that seeds of the groundnut genotypes differ in their response to ageing stress factors. Seeds of 'Samnut-24', 'Samnut-25' and 'Ex-Dakar' (R) were found to be more tolerant to ageing stress while 'Samnut 22' and 'Boro White' were susceptible to ageing stress. Optimum ageing for 24 hours is recommended for testing seeds of groundnut varieties for storage tolerance
\end{abstract}

Keywords: accelerated ageing; groundnut genotypes; seed germination; seedling vigour; storage tolerance

\section{Introduction}

Groundnut (Arachis hypogaea L.) is ranked the thirteenth among the important food crops and sixth most important oilseed crop in the world. It is a rich source of dietary fibre, minerals, and vitamins, containing

Received: 15 Oct 2020. Received in revised form: 20 Jan 2021. Accepted: 25 Jan 2021. Published online: 27 Jan 2021.

From Volume 13, Issue 1, 2021, Notulae Scientia Biologicae journal will use article numbers in place of the traditional method of continuous pagination through the volume. 
48-50\% oil and 26-28\% protein (Ntare et al., 2008). Groundnut production in West Africa averaged about 4.832 million tonnes, which represents about $60 \%$ of Africa's production and about $15 \%$ of world production (is grown on 26.4 million hectares worldwide with a total production of 37.1 million metric tonnes and an average productivity of 1.4 metric $\mathrm{t} / \mathrm{ha}$ (FAO, 2011). The productivity in Asia and America is relatively better with an average yield of 2.4 metric tonnes /ha and over 3.3 metric tonnes/ha respectively. Nigeria is the fourth largest producer of groundnut in the world and the largest groundnut producing country in West Africa, accounting for $51 \%$ of production in the region (Ajeigbe et al., 2015). Despite the numerous benefits and roles groundnut play at individual and national level in many developing countries, pod yield from farmers' field have remain low (Ndjeunga et al., 2010). Thus, effort has been concentrated on increasing land cultivated to meet up national demand. Increase in area of production has resulted to corresponding increase in seed requirement. Groundnut farmers often store their seeds under ambient condition where temperature and humidity can be very high, particularly in countries with warmer climate like Nigeria. There have been several studies on storability of groundnut seed. Dvssr et al. (2007) reported that groundnut seeds dried up to $4 \% \mathrm{mc}$ using sorption type drier with secondary refrigeration $\left(15^{\circ} \mathrm{C}\right.$ and $\left.15 \% \mathrm{RH}\right)$ can retain viability considerably for longer periods. Similarly, Rao et al. (2002) reported that groundnut seeds that is hermetically stored at room temperature $\left(23-25^{\circ} \mathrm{C}\right.$ ) with low moisture content (below $\left.4 \%\right)$ can retain high germination $(>85 \%)$ for up to 8 years. Other studies have argued that groundnut varieties react differently to environmental field conditions, like reaction to water stress, disease, and pest infection, with less information about genetic variability of groundnut seeds to storage stress. Most reports have stressed reduction in germination of groundnut seed during storage (Dvssr et al., 2007; Ameer et al., 2013) The reduction in germination of such crop seeds has been attributed to depletion of food reserves and decline in synthetic activity due to ageing, as well as bio-chemical changes of seed during storage (Ameer et al., 2013) This has become a serious concern to groundnut growers who need adequate, high quality seeds to sustain groundnut production, most especially in South Western Nigeria. In stimulating farmers' interest in groundnut production, there is a need to develop a sustainable seed availability strategy that will involve cultivation of varieties with moderate level of tolerance to storage stress under ambient condition in tropical climate. Therefore, this study is set to evaluate some groundnut varieties for their tolerance to seed ageing stress, with a view to recommending varieties that can be considered for production in Tropical countries.

\section{Materials and Methods}

\section{Germplasm collection}

Seeds of nine elite groundnut genotypes were sourced from The International Crops Research Institute of Semi-Arid Tropics (ICRISAT), Kano, while three genotypes were sourced from local seed dealer in Ibadan, Nigeria. Length and breadth of 10 seeds of each genotype were measured, using Vernier-calliper to calculate the surface area of the seeds $\left(\mathrm{mm}^{2}\right)$. The area of the seeds was used to classify the seed to sizes. Genotypes with seed area above $100 \mathrm{~mm}^{2}(>100)$ were classified as big, while genotypes with seed area between 70 to $99 \mathrm{~mm}^{2}$ were regarded as medium and genotypes with seed area less than $70 \mathrm{~mm}^{2}(<70)$ were regarded as small. The list of the genotypes and their seed characteristics are presented in Table 1, while the pictorial view of the seeds of the genotypes is presented in Figure 1. 
Table 1. Quantitative characteristics of the genotypes

\begin{tabular}{|c|c|c|c|c|}
\hline Genotypes & Source & Seed size & Seed coat texture & Seed colour \\
\hline 'Samnut-21' & ICRISAT, Kano & Big & Smooth & Whitish brown \\
\hline 'Samnut-22' & ICRISAT, Kano & Big & Smooth & Dark brown \\
\hline 'Samnut-23' & ICRISAT, Kano & Medium & Smooth & Light brown \\
\hline 'Samnut-24' & ICRISAT, Kano & Small & Smooth & Light brown \\
\hline 'Samnut-25' & ICRISAT, Kano & Small & Smooth & Light brown \\
\hline 'Samnut-26' & ICRISAT, Kano & Medium & Smooth & Light brown \\
\hline 'Ex-Dakar-Red' & ICRISAT, Kano & Medium & Smooth & Deep brown \\
\hline 'Ex-Dakar-W' & ICRISAT, Kano & Medium & Smooth & Brown \\
\hline 'Kuta-Red' & Local seed dealer & Big & Shrivel & Dark brown \\
\hline 'Boro-White' & Local seed dealer & Medium & Smooth & Light brown \\
\hline 'Boro-Red' & Local seed dealer & Medium & Smooth & Deep brown \\
\hline 'Kwankwaso' & ICRISAT, Kano & Medium & Shrivel & Brown \\
\hline
\end{tabular}

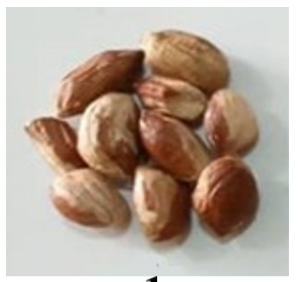

1

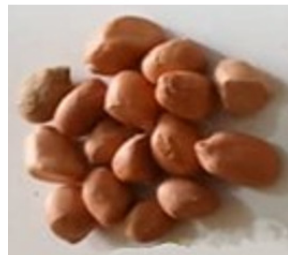

5

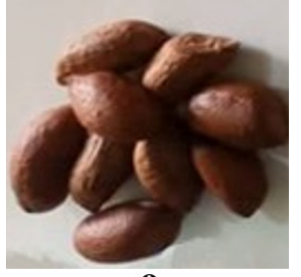

9

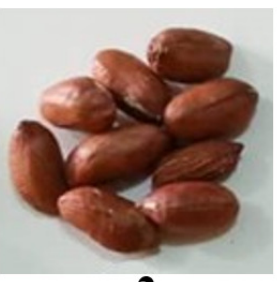

2

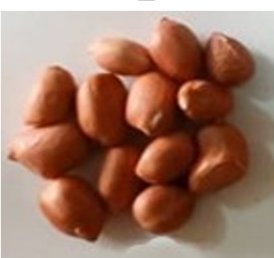

6

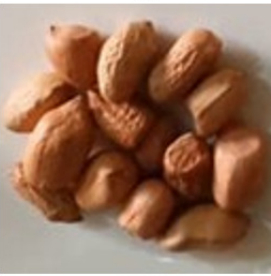

10

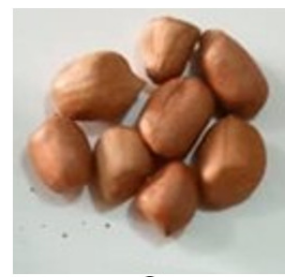

3

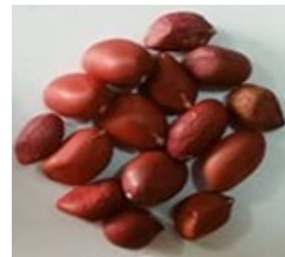

7

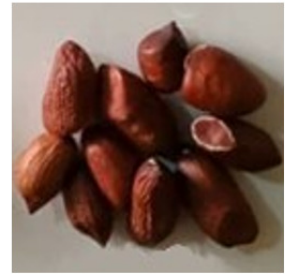

11

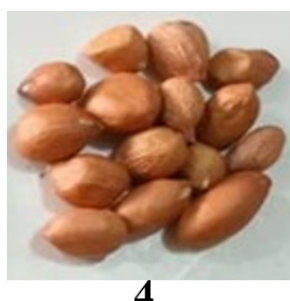

4

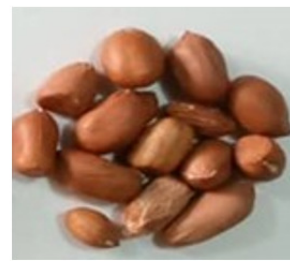

8

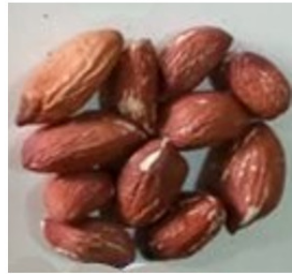

12

Figure 1. Pictorial view of groundnut genotypes

Keys: 1: 'Samnut-21', 2: 'Samnut-22'; 3: 'Samnut-23'; 4: 'Samnut-24'; 5: 'Samnut-25'; 6: 'Samnut-26';

7: 'Ex-Dakar-R', 8: 'Ex-Dakar-W’, 9: 'Kuta-Red'; 10: 'Boro-White'; 11: 'Boro-Red'; 12: 'Kwankwaso'

\section{Experimental location and procedure}

The experiment was carried out at the Seed Testing Laboratory of Institute of Agricultural Research and Training, Moor Plantation, Ibadan. The seeds of the collected genotypes were subjected to preliminary seed quality assessment as follows:

\section{Germination test}

50 seeds of each genotype were randomly picked in three replicates and planted in seed bowls filled with adequately moistened sterilized river sand. Seedlings were counted at 4, 6, 8, 10, 12 and 14 days after sowing. Germination percentage was calculated by finding the ratio of normal germinated seeds at 14 days after sowing to total number of seeds planted using the formula: 


$$
\mathrm{G}(\%)=\frac{\text { No of normal seedlings that germinated }}{\text { Total number of seeds planted }} \times 100 \text { (ISTA, 2020) }
$$

\section{Seed vigour assessment}

The vigour of the seeds of each genotype was assessed to determine the quality of life in the seeds. Germinating seedlings were counted on 4, 6, 8, 10,12 and 14 days after sowing. Also, seedling length of 5 randomly selected seedlings per pot were tagged and measured every two days, until the 14th day of planting, when the seedling weight of the tagged 5 seedlings were measured. Seedling vigour parameters were then estimated using the following procedures:

\section{Mean Germination Time (MGT)}

This is determined to estimate mean time required by each seed lot to initiate and end germination. It was estimated as:

MGT $=\frac{\Sigma(n T)}{\Sigma n}($ Mavi et al., 2010)

Where $\mathrm{n}$ is number of seeds newly germinated at time $\mathrm{T}$, while $\mathrm{T}$ is days from the beginning of the germination test.

Germination Index (GI)

This parameter emphasizes the germination percentage and the speed of germination. A higher germination index value implies a high germination percentage as well as the rate of germination (Al-Mudaris, 1998). It is estimated as:

$\mathrm{GI}=\frac{\Sigma(\mathrm{Nx})(\mathrm{DAP})}{\text { Total number of normal seedlings that emerged on final day }}$ (Akande et al., 2012)

where $\mathrm{Nx}$ is the number of normal seedlings that emerged on day $\mathrm{x}$ after seeding and DAP is days after planting

\section{Germination Rate Index (GRI)} follows:

This reflects the percentage of germination on each day of the germination period and was calculated as

$$
\mathrm{GRI}==\frac{G 1}{x}+\frac{G 2}{x}+\frac{G 3}{x}+\cdots \frac{G x}{x}(\text { Esechi, 1994) }
$$

where, $\mathrm{G}=$ germination on each day after seed placement $1,2, \mathrm{x}=$ corresponding day $\quad$ of germination

\section{Seedling vigour Index (SVI)}

The estimation of the seedling vigour index, involved the measurement of seedling length of five randomly selected seedlings of each replicate from the soil level at 8 and 14 days after planting. The SVI was then calculated as follows:

$$
\text { SVI }=\frac{(\text { Germination } \% \times \text { Seedling length })}{100}(\text { Adetumbi et al., 2019) }
$$

\section{Accelerated ageing procedure with corresponding germination and vigor test}

Clean seeds of the twelve genotypes were selected and subjected to accelerated ageing using a modified procedure of Ghosh et al. (2013) and Okunlola et al. (2020). A hundred seeds in three replicates of each genotype was counted and placed in an improvised plastic ageing box $(11.0 \times 11.0 \times 3.5 \mathrm{~cm})$, ensuring the seeds form a single layer. The ageing boxes has false bottom created through placement of wire mesh screen, which was suspended over $50 \mathrm{ml}$ distilled water to create $100 \%$ relative humidity during the ageing. The ageing boxes containing the seeds were arranged in the laboratory oven set at $42^{\circ} \mathrm{C}$. Twenty-five seeds of each genotype were drawn at 3, 6, 12 and 24 hours of ageing and placed on soft tissue paper to absorb excess moisture on the surface 
of the seed. Thereafter, the procedure for conducting preliminary assessment of the germination and vigour of the seed samples was used to evaluate each replicate of the aged seed lots of the genotypes to determine their tolerance ability of the seeds to ageing stress.

\section{Germination loss (G loss)}

This is the measure of the effect of the ageing on the germination percentage of the genotypes. It is measured by deducting the G\% of each genotype after the ageing at 3, 6, 12 \& 24 hours from the G\% before accelerated ageing (Initial G\%).

\section{Data analysis}

All percentage germination data was transformed using arc-sine formula. The preliminary seed germination and seedling vigour data, as well as the data obtained after the seed ageing were subjected to analysis of variance (ANOVA) using SAS ${ }^{\mathrm{m}}$ software. Significant means were separated using Duncan Multiple Range Test (DMRT) at 5\% level of significance while cluster analysis was conducted to group the genotypes based on their response to the ageing, using $\mathrm{k}$-means non-hierarchical clustering analysis.

\section{Results}

Mean square for seed germination and seedling vigour parameters for groundnut genotypes subjected to different ageing duration.

Seed ageing period significantly affected the seed quality variables except Mean Germination Time (MGT) at 5\% significance level (Table 2). Also, there were significant differences in the response of genotypes to artificial ageing at $5 \%$ significant probability. The interaction between ageing duration and genotypes was significant for seedling vigour index and seed germination parameters except germination loss. The result also showed that the coefficient of variance was highest in the germination loss (52.8), followed by germination index (17.6).

Table 2. Mean square for seed germination and seedling vigour parameters for groundnut genotypes subjected to different ageing duration

\begin{tabular}{|c|c|c|c|c|c|c|}
\hline SV & Df & G Loss (\%) & MGT (Days) & GRI & SVI & GI \\
\hline Ageing duration (A) & 4 & $2650.7^{*}$ & 0.79 & $13.6^{*}$ & $264.1^{*}$ & 733.1 \\
\hline Variety (V) & 11 & $444.82^{*}$ & $1.42^{*}$ & $2.42^{*}$ & $129.1^{*}$ & $4117.1^{*}$ \\
\hline A x V & 44 & 71.9 & $0.8^{*}$ & $0.9^{*}$ & $10.7^{*}$ & $542.6^{*}$ \\
\hline Error & 120 & 34.1 & 0.93 & 0.3 & 2.3 & 208.3 \\
\hline CV\% & & 52.8 & 10.3 & 13.9 & 12.1 & 17.6 \\
\hline
\end{tabular}

*Significant at $\mathrm{P}<0.05$ : SV = Source of variation, $\mathrm{Df}=$ Degree of freedom, GRI = Germination Rate Index;

GI = Germination index; SVI = Seedling Vigour Index; CV\% = Coefficient of Variation; Gloss = Germination loss MGT $=$ Mean germination time seeds

Effect of accelerated ageing duration on seed germination and seedling vigour parameters of groundnut

The result of the effect of accelerated ageing duration on germination and seedling vigour of groundnut showed that increase in ageing duration significantly reduces the germination of groundnut seeds. Also, there was significant increase in germination loss as the ageing period increases, while SVI, GI and GRI decreases. Although the mean of MGT recorded before ageing (4.9) and the mean recorded at 3, 6, 12 and 24 hours of ageing were close, there was no significant difference between the MGT of the seeds before ageing (4.9) and ageing at 3 (5.1) and 6 hours (5.0) of ageing. Most of the seeds germinated in about 5 days after planting (Table 3). 
Table 3. Effect of accelerated ageing duration on groundnut germination and seedling vigour of groundnut genotypes

\begin{tabular}{|c|c|c|c|c|c|c|}
\hline $\begin{array}{c}\text { Ageing duration } \\
\text { (Hours) }\end{array}$ & $\begin{array}{c}\text { Germination } \\
(\%)\end{array}$ & $\begin{array}{c}\text { G Loss } \\
(\%)\end{array}$ & $\begin{array}{c}\text { MGT } \\
(\text { Days })\end{array}$ & GRI & SVI & GI \\
\hline 0 & $76.2 \mathrm{a}$ & $0.0 \mathrm{e}$ & $4.9 \mathrm{~b}$ & $3.9 \mathrm{a}$ & $15.6 \mathrm{a}$ & $8.9 \mathrm{a}$ \\
\hline 3 & $69.5 \mathrm{~b}$ & $6.7 \mathrm{~d}$ & $5.1 \mathrm{ab}$ & $3.6 \mathrm{~b}$ & $14.3 \mathrm{~b}$ & $8.3 \mathrm{ab}$ \\
\hline 6 & $65.5 \mathrm{c}$ & $10.7 \mathrm{c}$ & $5.0 \mathrm{ab}$ & $3.5 \mathrm{bc}$ & $13.2 \mathrm{c}$ & $8.1 \mathrm{~b}$ \\
\hline 12 & $61.1 \mathrm{~d}$ & $15.1 \mathrm{~b}$ & $5.2 \mathrm{a}$ & $3.3 \mathrm{~cd}$ & $10.9 \mathrm{~d}$ & $8.0 \mathrm{~b}$ \\
\hline 24 & $53.4 \mathrm{e}$ & $22.8 \mathrm{a}$ & $5.3 \mathrm{a}$ & $3.2 \mathrm{~d}$ & $8.8 \mathrm{e}$ & $7.7 \mathrm{~b}$ \\
\hline
\end{tabular}

Means followed by same alphabet along the column are not significantly different at $\mathrm{P}<0.05$ according to DMRT

GRI = Germination Rate Index; GI = Germination index; SVI = Seedling Vigour Index;

Gloss $=$ Germination loss $\mathrm{MGT}=$ Mean germination time

Effect of accelerated ageing on seed viability and seedling vigour characteristics of groundnut genotypes.

There was significant difference in the germination loss and seedling vigour characteristics of the groundnut genotypes (Table 4). 'Samnut 24' recorded the lowest germination loss (3\%) after ageing. This was followed by 'Samnut 25' that recorded the mean value of 6\% germination loss. 'Boro Red' recorded the highest germination loss (21\%), followed by 'Samnut 21' (20.5\%). Although the MGT recorded by the groundnut genotypes after ageing were very close, there were significant differences in the MGT recorded among the genotypes. 'Samnut-24' germinated earlier than all the genotypes at 4 days after planting while 'Kwankwanso' significantly germinated later at 6 days after planting. Most of the genotypes germinated at 5 days after at planting. The GRI of 'Samnut-24' (5.5) was the highest, followed by 'Samnut-25' and 'Samnut-26' that recorded 4.9 and 4.1 respectively while 'Samnut-21' and 'Kwankwaso' recorded the lowest GRI of 2.4 and 2.5 respectively (Table 4). The Seedling Vigour Index indicated no significant difference between 'Samnut 24' and 'Samnut 25'. Also, there was no significant difference between 'Samnut 26', 'Ex-dakar Red', 'Ex-dakar white' and 'Kuta Red' while 'Samnut 23' and 'Samnut 21' recorded the lowest SVI of 8.6 and 8.3 respectively. 'Exdakar Red' and 'Samnut-25' recorded the highest GI (10.7) followed by 'Samnut 24' (10.0) while 'Samnut 21' recorded the lowest GI (5.8).

Table 4. Mean value of seed germination loss and seedling vigour parameters of groundnut genotypes after artificial ageing

\begin{tabular}{|c|c|c|c|c|c|}
\hline Groundnut genotypes & G Loss $(\%)$ & MGT (Days) & GRI & SVI & GI \\
\hline 'Samnut-21' & $20.5 \mathrm{a}$ & $5.0 \mathrm{bc}$ & $2.4 \mathrm{f}$ & $8.3 \mathrm{f}$ & $5.8 \mathrm{~g}$ \\
\hline 'Samnut-22' & $12.9 \mathrm{~b}$ & $5.1 \mathrm{bc}$ & $3.1 \mathrm{de}$ & $11.7 \mathrm{~cd}$ & $7.6 \mathrm{de}$ \\
\hline 'Samnut-23' & $8.1 \mathrm{c}$ & $4.7 \mathrm{~cd}$ & $3.0 \mathrm{de}$ & $8.6 \mathrm{ef}$ & $6.8 \mathrm{efg}$ \\
\hline 'Samnut-24' & $2.9 \mathrm{~d}$ & $4.4 \mathrm{~d}$ & $5.5 \mathrm{a}$ & $17.3 \mathrm{ab}$ & $10.0 \mathrm{ab}$ \\
\hline 'Samnut-25' & $6.1 \mathrm{~cd}$ & $4.8 \mathrm{~cd}$ & $4.9 \mathrm{~b}$ & $16.5 \mathrm{a}$ & $10.7 \mathrm{a}$ \\
\hline 'Samnut-26' & $9.9 \mathrm{bc}$ & $5.1 \mathrm{bc}$ & $4.1 \mathrm{c}$ & $14.6 \mathrm{~b}$ & $9.3 \mathrm{bc}$ \\
\hline 'Ex-Dakar-R' & $9.6 \mathrm{bc}$ & $5.2 \mathrm{bc}$ & $4.0 \mathrm{c}$ & $14.3 \mathrm{~b}$ & $10.7 \mathrm{a}$ \\
\hline 'Ex-Dakar-W' & $10.1 \mathrm{bc}$ & $5.1 \mathrm{bc}$ & $3.8 \mathrm{c}$ & $13.5 \mathrm{~b}$ & $8.7 \mathrm{~cd}$ \\
\hline 'Kuta-Red' & $13.3 \mathrm{~b}$ & $5.4 \mathrm{ab}$ & $3.2 \mathrm{~d}$ & $13.8 \mathrm{~b}$ & $7.8 \mathrm{de}$ \\
\hline 'Boro-White' & $7.6 \mathrm{c}$ & $5.4 \mathrm{ab}$ & $3.0 \mathrm{de}$ & $12.0 \mathrm{e}$ & $7.5 \mathrm{def}$ \\
\hline 'Boro-Red' & $21.0 \mathrm{a}$ & $5.2 \mathrm{bc}$ & $2.8 \mathrm{ef}$ & $10.7 \mathrm{~d}$ & $6.4 \mathrm{fg}$ \\
\hline 'Kwankwaso' & $9.9 \mathrm{bc}$ & $5.6 \mathrm{a}$ & $2.5 \mathrm{f}$ & $9.6 \mathrm{e}$ & $7.0 \mathrm{ef}$ \\
\hline
\end{tabular}

Mean with same letters in the same column are not significantly different at $\mathrm{p}<0.05$ according to DMRT

GRI = Germination Rate Index; GI = Germination index; SVI = Seedling Vigour Index;

Gloss $=$ Germination loss $\mathrm{MGT}=$ Mean germination time 
Interaction between groundnut genotypes and ageing duration on germination loss

The response of the groundnut genotypes to accelerated ageing duration as recorded by the germination loss showed that, there was a sharp increase in germination loss for 'Samnut-21' at the ageing duration of 0 to 3 hours, while 'Boro-white' has a steady germination loss till 6 hours of ageing. There was no significant germination loss after 3 hours of ageing for 'Samnut-24', after which, there was a steady low germination loss till 24 hours ageing. All the genotypes recorded varied level of germination loss as the ageing period increases to 24 hours (Figure 2).

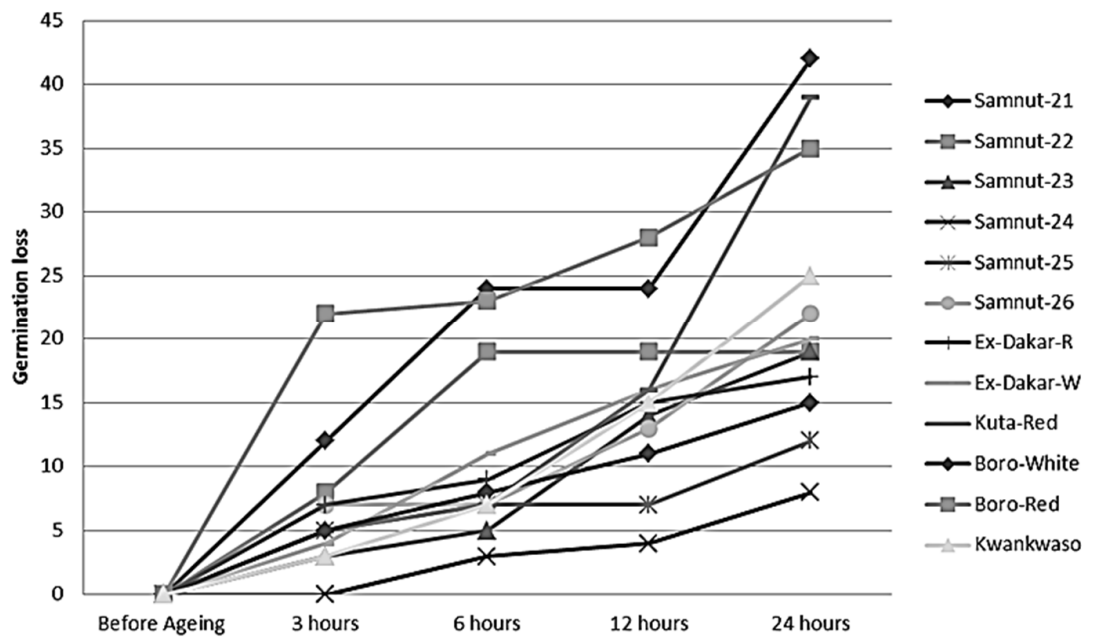

Figure 2. Interaction between groundnut genotypes and accelerated ageing duration on germination loss

Degree of relationship among groundnut varieties based on seed germination loss and seedling vigour characters after 24 hours of accelerated ageing:

The dendrogram drawn from the Single Linkage Cluster Analysis (SLCA) illustrating the relationship between the 12 genotypes based on seed germination loss and seedling vigour characters after 24 hours of accelerated ageing shows that seed of all the groundnut genotypes were different from each other at minimum distance of $0.00 \%$ level based on their reaction to ageing stress. Two main clusters (A and B) were identified among the groundnut genotypes at $16 \%$ distance level while four groups are distinguishable between $8 \%$ and $12 \%$ distance level. Group 1 comprises of five genotypes ('Boro white', 'Samnut 22', 'Kuta Red', 'Samnut 23' and 'Kwankwaso') which are less tolerant to ageing stress. Both group 2 ('Boro Red', 'Samnut 21') and 3 ('Samnut 26', 'Ex-Dakar White') has 2 genotypes each that are moderately tolerant to ageing stress. Group 4 has 3 genotypes ('Samnut 24', 'Samnut 25', 'Ex-Dakar Red') that are more tolerant to ageing stress (Figure 3).

\section{Discussion}

High temperature and relative humidity are among the major storage stresses that confronts seed during storage. Accelerated ageing technique has been widely used to access the ability of seeds to resist storage stress. In this study, accelerated ageing duration affected the seed quality of groundnut genotypes. The germination loss recorded in groundnut seed increases as the ageing duration increases. This implied that groundnut seeds are sensitive to changes in storage temperature and relative humidity. Germination percentage and mean germination time of groundnut seed were affected at high RH irrespective of the species. 


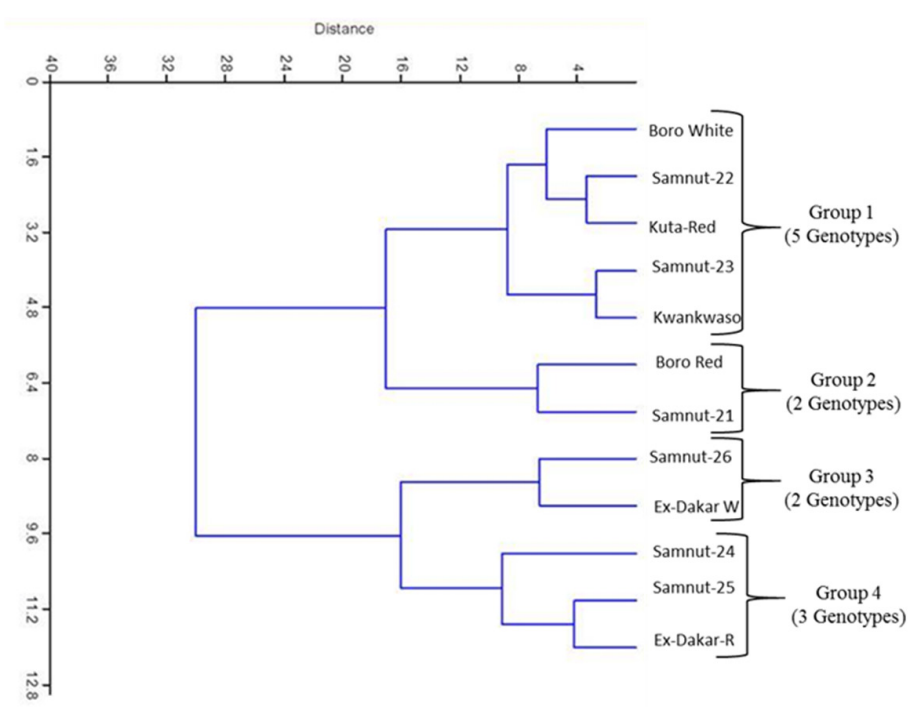

Figure 3. Dendrogram grouping of groundnut genotypes based on germination loss and all seed vigour characteristics after accelerated ageing

A similar report on some oil seed crops Brassica spp (Suma et al., 2013) and Glycine max (Jagadish et al., 2012) revealed that storage at intermediate relative humidity of about $32 \%$ causes minimal decline in viability. The significant variations in the response of genotypes to accelerated ageing in terms of percentage germination loss, seedling vigour index and other seedling germination parameters confirms that seed deterioration in groundnut is inevitable, but responses of the genotypes to ageing factor differs. The variation can be attributed to genetic make-up of the genotypes. Kapoor et al. (2010) has reported that varieties of chickpea responded differently with reference to physiological and biochemical changes occurring due to seed ageing. Similarly, Okunlola et al., (2020) attributed significant variation in germination and other seedling vigor parameters recorded under artificial aging treatments to different genetic makeup of the soybean varieties.

Groundnut genotypes with small seed sizes were significantly low in germination loss with high seedling vigour characteristics. This implies that genotypes with small seed size are more tolerant to ageing stress than the other varieties with bigger kernels. Peksen et al. (2004) has reported that cultivars of pea (Pisum sativum L.) with low 100 seed weight had higher germination percentage than seeds with larger 100 seed weight. Similarly, Rastegar and Kandi (2011) observed that small seeds had better and faster germination than larger ones in soybean. Cluster analysis has been described to have the ability to identify crop genotypes with the highest level of similarity (Aliyu and Fawole, 2000). The cluster analysis identified four groups among the groundnut genotypes with varied level of tolerance to ageing stress. The tolerant genotypes ('Samnut 24', 'Samnut 25', 'Ex-Darka R') clustered together could be linked to their inherent genetic potential to withstand storage stress, while the susceptible genotypes; 'Samnut 22', 'Boro White', 'Kuta Red' might require improvement in their genetic makeup for cultivation among resource poor farmers that might need to preserve seeds under ambient condition.

\section{Conclusions}

Groundnut genotypes differ in their response to ageing stress factors. Seeds of 'Samnut-24', 'Samnut-25' and 'Ex-Dakar-Red' were found to be more tolerance to ageing stress and are likely to be easily adopted for production among farmers. Accelerated ageing of 24 hours significantly affected groundnut seed germination and seedling vigour. Therefore, an optimum ageing of about 24 hours is recommended for testing seeds of groundnut varieties for storage tolerance. 


\section{Authors' Contributions}

Conceptualization: KOSA, TOK and JAA, Laboratory work and data curation: KOSA and JAA, Technical Supervision TOK and MAA, Data analysis and interpretation KOSA, DJO and JAA, Manuscript writing and review: TOK, KOSA, DJO and JAA. All authors read and approved the final manuscript.

\section{Acknowledgements}

This research received no specific grant from any funding agency in the public, commercial, or not-forprofit sectors. However, ICRISAT, Nigeria is appreciated for providing seeds of the elite groundnut varieties.

\section{Conflict of Interests}

The authors declare that there are no conflicts of interest related to this article.

\section{References}

Adetumbi JA, Orimadegun IO, Akinyosoye ST, Akintayo OT, Agbeleye OA (2019). Enhancing planting value of rice seed through priming with humic substance. Journal of Experimental Agriculture International 29(6):1-8. https://doi.org/10.9734/JEAI/2019/46194

Ajeigbe HA, Waliyar F, Echekwu CA, Ayuba K, Motagi BN, Eniayeju D, Inuwa A (2015). A farmer's guide to groundnut production in Nigeria. Patancheru 502 324, Telangana, India: International Crops Research Institute for the Semi-Arid Tropics, pp 36. http://oar.icrisat.org/8856/1/2015-084\%20Gnut\%20Production\%20in\%20Nigeria.pdf.

Akande SR, Olakojo SA, Ajayi SA, Owolade OF, Adetumbi JA, Adeniyan ON, Ogunbodede BA (2012). Planting date effects on cowpea seed yield and quality at Southern Guinea Savannah of Nigeria. Seed Technology 34:979-988. https://stjournal.org/volume-34-no-1-2012/.

Aliyu B, Fawole I (2000). Inheritance of pubescence in crosses between Vigna unguiculata and V. rhomboidea. Nigerian Journal of Genetics 15:9-14. https://doi.org/10.4314/njg.v15i1.42267.

Al-Mudaris MA (1998). Notes on various parameters recording the speed of seed germination. Journal of Agriculture in
the
Tropics
and
Subtropics
99
(2):147-154 https://www.jarts.info/index.php/tropenlandwirt/article/view/1495

Ameer Junaithal Begum M, Venudevan B, Jayathi M (2013). Storage fungi in groundnut and the associate seed quality deterioration: A review. Plant Pathology Journal 12 (3):127-134. https://doi.org/103923/ppj2013.127.134.

Chowdhury RK, Mathur DS, Lal SK, Jayaprakash P (2003). Seed research on groundnut under NSP Crops - An overview. Proceeding of National Workshop on Groundnut Seed Technology, University of Agricultural Science, Dharwad, February 6-7, pp 6-19.

Esechie HA (1994). Interaction of salinity and temperature on the germination of sorghum. Journal of Agronomy and Crop Science 172:194-199. https://doi.org/10.1111/j.1439-037X.1994.tb00166.x.

Ghosh A, Singh VJ, Gampala S, Sahoo P, Chakraborti SK (2015). Response of groundnut treated seed to accelerated $\begin{array}{llll}\text { ageing. } & \text { Environment } & \text { 33(3):1192-1195. }\end{array}$ https://drive.google.com/file/d/1v4iOJGKjq3DcMdmj72tgkH18dd64APoA/view

ISTA (2020). International Rules for Seed Testing. The Germination tests. Volume 2020(1):1-14 https://doi.org/10.15258/istarules.2020.05.

Jagadish SVK, Septiningsih EM, Kohli A, Thomson M J, Ye C, Redoña E, Singh R K (2012). Genetic advances in adapting rice to a rapidly changing climate. Journal of Agronomy and Crop Science 198(5):360-373. https://doi.org/10.1111/j.1439-037X.005252012.x. 
Kapoor N, Arya A, Siddiqui MA, Amir A, Kumar H (2010). Seed deterioration in chickpea (Cicer arietinum L.) under accelerated ageing. Asian Journal of Plant Sciences 9:158-162. https://doi.org./10.3923/ajps.2010.158.162.

Mavi K, Demire I, Matthews S (2010). Mean germination time estimates the relative emergence of seed lots of three cucurbit crops under stress conditions. Seed Science and Technology 38:14-25. https://doi.org/10.15258/sst.2010.38.1.02.

Ndjeunga J, Ntare BR, Abdoulaye A, Ibro A, Zarafi MA, Cisse Y, ... Micko I (2010). Farmer preferences for groundnut traits and varieties in West Africa: Cases of Mali, Niger and Nigeria, Working Paper Series no. 27. Patancheru 502 324, Andhra Pradesh, India: International Crops Research Institute for the Semi-Arid Tropics. 32pp. http://oar:icrisat.org/221/

Ndjeunga J, Ntare BR, Waliyar F, Echekwu CA, Kodio O, Kapran I, ... Da Sylva A (2008). Early adoption of modern groundnut varieties in West Africa. Working Paper Series No. 24. Sahelian Center, BP 12404 Niamey, Niger: International Crops Research Institute for the Semi-Arid Tropics, pp 62. http://oar.icrisat.org/6795/

Ntare BR, Diallo AT, Ndjeunga J, Waliyar F (2008). Groundnut seed production manual. International Crops Research Institute for the Semi-Arid Tropics (ICRISAT), Andhra Pradesh, India. http://oar.icrisat.org/420/1/CO_200803.pdf.

Okunlola G, Idehen E, Adetumbi J, Alake C, Akinyosoye S, Amusa O (2020). Genetic studies of soybean [Glycine max (L.) Merr.] response to seed storage stress factors. Acta Agriculturae Slovenica 116(1):23-34, https://doi:10.14720/aas.2020.116.1.1181.

Peksen E. Peksen A, Bozoglu H, Gulumser A (2004). Some seed traits and their relationships to seed germination and field emergence in Pea (Pisum sativum L.). Journal of Agronomy 3:243-246. https://doi.org/10.3923/ja.2004.243.246.

Rao NK, Dvssr S, Bramel PJ (2002). Effects of shell and low moisture content on Peanut seed longevity. Peanut Science 29:122-125. https://www.peanutscience.com/doi/pdf/10.3146/pnut.29.2.0008.

Rastegar Z and Kandi MAS (2012). The effect of salinity and seed size on seed reserve utilization and seedling growth of soybean (Glycin max). Journal of Seed Science and Technology 1:1-5. https://www.sid.ir/en/journal/ViewPaper.aspx?ID=276630

Sastry DVSSR, Upadhyaya HD, Gowda CLL (2007). Survival of groundnut seeds under different storage conditions. Journal of SAT Agricultural Research 5:3. http://ejournal.icrisat.org/volume5/Groundnut/gn4.pdf.

Suma A, Sreenivasan K, Singh AK, Radhamani J (2013). Role of relative humidity in processing and storage of seeds and assessment of variability in storage behaviour in Brassica spp. and Eruca sativa. The Scientific World Journal 19 https://doi.org/10.1155/2013/504141.
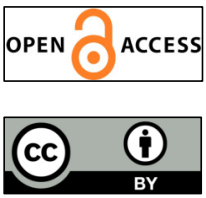

The journal offers free, immediate, and unrestricted access to peer-reviewed research and scholarly work. Users are allowed to read, download, copy, distribute, print, search, or link to the full texts of the articles, or use them for any other lawful purpose, without asking prior permission from the publisher or the author.

License - Articles published in Notulae Scientia Biologicae are Open-Access, distributed under the terms and conditions of the Creative Commons Attribution (CC BY 4.0) License.

(c) Articles by the authors; SHST, Cluj-Napoca, Romania. The journal allows the author(s) to hold the copyright/to retain publishing rights without restriction. 